\title{
Incentive/disincentive contracts and its effects on industrial projects
}

\author{
Abdulaziz A. Bubshait* \\ Construction Engineering and Management, King Fahd University of Petroleum and Minerals, PO Box 960, Dharan 31261, Saudi Arabia
}

Received 14 October 2001; accepted 22 October 2001

\begin{abstract}
Project delays and cost overruns are becoming major problems in many projects, especially industrial projects. The present economic situation has forced owners to establish time and cost reduction programs to control expenditure. The main objectives of this study are to study the perceptions of owners and contractors about incentive/disincentive (I/D) contracting. A questionnaire was used to gather the required data for the study. This was distributed among owners and contractor companies working in petrochemical plants, power plants, and refineries. The findings of the study support the use of I/D provisions in contracts. In addition, the use of $\mathrm{I} / \mathrm{D}$ contract provisions ensure that contractors do their utmost to manage and control factors that influence labor productivity, project duration and/or project cost. (C) 2002 Elsevier Science Ltd and IPMA. All rights reserved.
\end{abstract}

Keywords: Industrial projects; Contract administration; Incentive contract; Contractor performance; Contract penalty; Saudi Arabia

\section{Introduction}

The construction of industrial projects such as petrochemical plants, power generation plants and refineries involves complex processes. Proper scheduling and planning of project activities is vital to avoid construction delays and other difficulties during the construction phase. A 1-day production delay in an industrial plant can cost the company millions of dollars. It is not uncommon in the construction of industrial plants to provide performance incentives to contractors for early completion, quality work and adherence to safety rules and regulations.

Incentive and disincentive (I/D) contracting is intended to reward or penalize the contractor based on performance. The amount of $I / D$ is normally determined by the owner, and then negotiated with the contractors. Owners usually offer schedule incentives for early project completion, quality incentives for high quality work and sometimes safety incentives for complying with the safety rules and regulations of the company. Other incentives can also be given to the contractor such as incentives for innovations that lead to a cost saving for the owner. On the other hand, disincentives are set to penalize the contractor for bad performance.

\footnotetext{
* Tel. + 966-3-860-3709; fax: +966-3-860-4453.

E-mail address: bushait@kfupm.edu.sa
}

Schedule incentives and disincentives represent the most common type used for I/D contracting. In this case, the owner sets a reward for each day of early project completion and penalizes the contractor for each of day delay beyond the specified project completion date. Due to the nature of industrial projects, there are several factors that can adversely affect project duration and cost. Contractors need not only be aware of these factors but they need to plan to minimize or eliminate their effects. Imposing I/D clauses in the contract will compel contractors to make the extra effort to find solutions to these factors. Also the I/D contract helps owners to achieve their goals by encouraging and forcing contractors to comply with their requirements. While owners pay some extra money in terms of incentive, they gets back a return on their investment through early project completion. On the other hand, contractors deserve the incentive as a reward for excellent work and early project completion.

This paper discusses the effect of using incentive/disincentive provisions in industrial projects. Specifically, the paper answers the following questions for the I/D schedule contract: what are the extra measures that contractors have to take in I/D contracting? How do owners determine the amount of incentive and disincentive? What are the problems of $\mathrm{I} / \mathrm{D}$ contracting? How do owners select I/D projects? What is the criterion used to define the completion of the project in $\mathrm{I} / \mathrm{D}$ 
contracting? What are the types of $\mathrm{I} / \mathrm{D}$ contract? And finally, what is the optimal I/D amount per project?

\section{Types of incentive contract}

The common types of incentive contract used in the construction industry include the following:

1. The first is the fixed price incentive contract, which is divided into (a) guaranteed maximum, and (b) bonus/penalty incentives. The guaranteed maximum is most effective when the contractor has some control over the design phase of the project as in the design-build contract. The main purpose of the bonus/penalty incentive contract is to reward contractors for early completion of the work or penalize them for late completion. It is feasible to combine the three types of incentive contract (cost, technical, schedule) contract in a project; however, the owner should make sure that conflicts do not exist between them [1].

2. Second is the cost reimbursable contract with and without incentive. This type provides a positive incentive to the contractor to increase cost; therefore its use is not advisable and should be limited. If it is necessary to use this type of contract, then it should be limited to low cost projects, emergency work, and short duration projects. The performance incentive contract is used when the performance of the work is of great importance to the owner.

3. Third is the performance incentive. The contractor's incentive is based on contractor performance as evaluated and determined by the owner. The evaluation intervals and the performance criteria must be established in the contract. Performance generally is measured on things that have an effect on the schedule or cost such as quality, safety, technical management, utilization of resources, productivity and responsiveness [2].

4. Fourth is the safety incentive. The literature offers limited support to the value of safety incentives. Safety research supports the fact that safety incentives may have some influence on improving safety performance; however, their influence will not guarantee the success of the safety program (Hinze, 1987).

\section{Establishing project duration}

Normally the duration of a project in I/D contracting is established based on similar projects or by past performance. Two schedules are developed, namely, normal and expedited. The normal schedule is based on a 5 -day week and $8 \mathrm{~h}$ a day. This schedule is then compressed into an expedited schedule with a 6- or 7day week and extended working hours. There is general agreement between owners and contractors that this method is widely used to determine the project duration in $\mathrm{I} / \mathrm{D}$ contracting [3].

\section{Contracting problems}

The following are the most common problems encountered in I/D contracting as noted by Arditi and Yasamis [3]: scheduling difficulties, contract language interpretation, crew redundancy affecting productivity, working in adverse weather conditions to maintain the schedule, adverse relationships within the contractor's team resulting from the pressure of trying to achieve the maximum incentive, delays in the review of drawings and change order approvals, and sacrificing quality for speed.

\section{Contractor performance}

The contractor's ability to reduce project cost to a minimum is an important measure of his performance. In contracts where project amount is fixed such as lump-sum contracts, reducing contract execution time is an important measure of contractor performance. During construction progress, several aspects can be checked by the project owner to see how well the contractor is doing in order to have sound and reliable performance records and not to be surprised by work shutdowns and project delay, contractor bankruptcy or other problems which cause project cost overruns. For a listing of these aspects refer to Clough [4].

\section{The case study}

The study was carried out in Jubail industrial city, Saudi Arabia. Jubail hosts SABIC affiliated companies. This affiliation consists of more than 14 companies producing chemical, petrochemical and steel products. In addition, several other large and small companies are also located in the area. Several industrial projects, either new projects or extension to the existing facilities, are currently in progress. The questionnaire developed by Arditi and Yasamis [3] was used as the basis in developing the questionnaire for this study. The questionnaire (in the Appendix) covered various aspects of $\mathrm{I} / \mathrm{D}$ contracting. In addition to SABIC affiliate companies, an electrical power plant, an oil refinery, and contractors working with these companies were included in the study population. The selection criteria were: (a) owner and contractor companies with more than 50 employees; and (b) wellestablished Saudi and joint Saudi ventures companies with more than 5 years of experience in Saudi Arabia. 
A number of companies and contractors were asked to participate in the study. Only 40 (20 owner and 20 contractors companies) showed preliminary interest. The total number of responses was 21: 11 responses from owners, and 10 responses from contractors. The owners included nine petrochemical companies with the number of employees ranging from 800 to 1000; one oil and refinery company with about 6000 employees exceeding 55,000; and an electrical power company with number of employees about 6000 . The contractors included six general contracting companies with the number of employees ranging between 1500 and 1700; one heavy industry company with 1000 employees; two siren alarm system companies each with an average employment of 50; and one air-conditioning maintenance company with employees of 50 . The study findings are presented in the appendix and discussed below.

\section{Contracting milestone setting}

The first two questions discuss the $\mathrm{I} / \mathrm{D}$ contracting milestone setting. A critical problem in preparing a schedule in an I/D contract is the accurate determination of the target contract duration by the owner before the invitation to bidders. The target contract duration is important since the I/D payments are made by using the target contract duration as a benchmark. The method most widely used to calculate project duration is based on similarly constructed projects or past performance. Some owners develop a two-project schedule: namely, a master schedule and a detailed schedule. The master schedule contains general information about the engineering procurement of long lead equipment and materials. As more accurate information is obtained, it is included in the schedule. This schedule is called the "detailed project schedule", and is most probably used to set the contract target duration.

In response to question (1) regarding the incentive payment method to the contractor, there is a partial agreement between the two parties that the incentive should be paid in full upon completion of the project. One of the important aspects in $I / D$ provisions is the definition of project completion [question (2)]. The variation between the owners and contractors regarding the criterion used to define the completion of the project is obvious. About $27.3 \%$ of the owners said that project turnover to operation, start-up, and commissioning are the most widely used criteria to define project completion. On the other hand, $70 \%$ of the contractors stated that mechanical completion is the criterion that should be used to define the project completion. The project is mechanically completed when all field related physical construction activities are completed.

\section{Project implementation}

I/D contracts are generally fast track projects in order to meet early project completion targets. Consequently, contractors should not ignore or forget to monitor and control costs. In response to question (3), $82 \%$ of the owners indicated that early completion would insure a rapid return on investment, this being the main reason for owners to specify incentives; and $60 \%$ of contractors were not able to state why a certain project should be selected as an incentive project. It seems that most contractors are unaware of the reasons for including incentive provisions in a contract. The idea behind using $\mathrm{I} / \mathrm{D}$ provisions should be better communicated to contractors in order to achieve the owners' goals.

The stage at which I/D provisions are included in the contract is significant [question (4)]. Some owners prefer to include $\mathrm{I} / \mathrm{D}$ provisions after the bidding or during negotiations with the successful bidder. Their aim is to lower the bidding price. They believe that if I/D provisions are included at the bidding stage the project cost will rise; since contractors add contingencies in their bids. Owners believe that it is not to their benefit to include $\mathrm{I} / \mathrm{D}$ in the bidding especially for fixed price contracts. About $64 \%$ of owners indicated that the $\mathrm{I} / \mathrm{D}$ should be included in the negotiation stage, while $60 \%$ of contractors state that it should be included at the construction stage, since in most cases they are not involved in the project until all the engineering and design packages are completed.

\section{Contractors' related work practices}

Question (5) was asked to determine the extra measures that a contractor needs to undertake in $\mathrm{I} / \mathrm{D}$ contracting. Sixty percent of the contractors said that the first thing that a contractor has to undertake is to add more manpower. On the other hand, $45 \%$ of the owners said that contractors need to use advanced equipment, machines, construction techniques, and increase workers' productivity by providing motivation and proper planning and scheduling. There is a distinct variation between the owners' and contractors' perceptions regarding the extra measures contractors need to undertake in I/D projects. This variation may be due to the differences in goals and objectives.

Proper communication is vital for the success of any project. The contracting parties should maintain good lines of communication to share the same objectives to guarantee that all parties involved benefit from the contract. Question (6) discussed the communication process between the owner and the contractor. A 100\% agreement between contractors was obtained. They all think that regular meetings should be the proper line of communication while only $54.5 \%$ of the owners agreed on this point. 
In response to question (7) regarding the managerial techniques that contractors should use in $\mathrm{I} / \mathrm{D}$ contracting, $90 \%$ of the contractors indicate that a bar chart should be used while only $54.5 \%$ of owners supported the use of bar charts. The reason for the high ranking given to the bar chart relates to its simplicity. On the other hand, the critical path method (CPM) is not used by most contractors since it needs skilled planners to operate it.

Whether the contractor should use more manpower and equipment to meet the project's early completion is discussed in question (8). The result shows that the most frequently used method by contractors is seven workdays with multiple crews in different locations. However, owners think that contractors should work only 6 workdays a week with multiple crews in different sites. This is a realistic approach since it is very hard for workers to work continuously for the whole week especially for a long duration project. Workers' productivity will undoubtedly be lowered due to long working periods and related illnesses.

Regarding manpower policy [question (9)], two measures were suggested: (a) the contractor needs to adept a policy of selecting field personnel $(70 \%)$, and (b) the contractor needs to establish a system of selecting subcontractors $(50 \%)$. Some $45.5 \%$ of owners suggested that contractors should focus first on selecting subcontractors, followed by the selection of qualified field superintendents and supervisors. Moreover, owners think that selecting a senior management team is not as important as selecting subcontractors in $\mathrm{I} / \mathrm{D}$ contracting.

Motivation, especially, monetary motivation, has proven its influence on the productivity of workers. Sometimes moral motivation is also important to promote the productivity of the work crew. About $27.3 \%$ of the owners indicated that the incentive should be passed to middle management while only $9.1 \%$ said it should be passed to workers. Fifty percent of the contractors said that the incentive should be passed to workers and only $20 \%$ stated that it should be passed to middle management.

In response to question (11), both parties agree that contractors have some problems in increasing labor productivity. Several factors can negatively affect labor productivity. Contractors should be aware of these factors and try to eliminate them or mitigate their effects.

\section{Comparison of $I / D$ versus non- $I / D$ contracts}

In conventional contracting methods, most owners suffer from change orders imposed by contractors. Some contractors make a good profit from change orders. Questions (12) and (13) discussed the frequency and the magnitude of change orders in $\mathrm{I} / \mathrm{D}$ projects compared to non-I/D projects. Both parties said that they did not know the exact answer to this question ( $80 \%$ contractors, $36.4 \%$ owners). This probably is due to the small sample size and the lack of records. Perhaps further study should be done to draw valid conclusions.

Regarding the magnitude of change orders [question (13)], $70 \%$ of the contractors said that they did not know; while only $27.3 \%$ of the owners stated that the magnitude of change orders in $\mathrm{I} / \mathrm{D}$ project was less than an average non-I/D project. In response to question 14 , 45.5 and $60 \%$ of owners and contractors, respectively, agreed that non-I/D projects generally last longer than $\mathrm{I} / \mathrm{D}$ projects, however, no one specified the percentage of how much longer non-I/D project last I/D projects. Incentive contracting is set for some projects to promote timely and quality work without exceeding the assigned budget. Owners incorporate I/D clauses to motivate contractors to use their maximum power to fulfill the contract requirement. Question (15) was about the advantages of I/D contracting to owners. Ninety percent of the owners and $70 \%$ of the contractors commented that the incorporation of $\mathrm{I} / \mathrm{D}$ provisions was to encourage contractors to expedite the construction work.

\section{Fee calculations}

I/D fee calculations are discussed in questions (16)(20). It is important for a firm to have a mechanism for calculating I/D amounts for a project. The majority of companies do not have a systemic procedure to calculate the amount of I/D fees [questions (16) and (17)]. Some companies use a percentage of the total contract cost as an I/D fee.

Although both parties did not agree on a fixed percentage of optimal amount of incentive per project, they suggested that the amount of I/D should depend on the criticality of the project and the risk sharing (63.3\% owners, $80 \%$ contractors). The majority of them do not have a system to assign I/D fees. Some companies do not include incentive clauses in their contracts; they specify only penalties for late completion. They think that penalties will force contractors to be proactive and will try to increase the work productivity to meet the contract deadlines. In response to question (20) about whether the amount of incentive and disincentive be assigned equally or one higher than the other, the parties vary in their answers. The majority of owners (54.5\%) stated that the incentive and penalty should be equal. However, as expected, the majority of the contractors $(80 \%)$ said that the incentive should be more than penalty.

\section{Conclusions and recommendations}

This research highlights the variation in owner and contractor perception about incentive/disincentive 
contracting in industrial projects. Most of the respondents agree on the effectiveness of I/D contracting in promoting contractor performance while few companies use I/D contracting in their contracts.

Most of the companies who participated in the survey use a penalty system rather than an incentive system to penalize the contractor for late completion. Only one company was found having a written formula to calculate the amount of penalty; other companies do not have any form to calculate the amount of I/D fee. In most cases they use a percentage of the contract price as a base to provide the $\mathrm{I} / \mathrm{D}$.

Project delay and cost overruns are a nightmare especially in industrial projects. Several reasons contribute to this problem, among them are: poor planning, low productivity, inadequate resources, inaccurate estimates. Many companies are trying to resolve this problem by imposing penalties on contractors for late project completion. They do not use incentives simply because they think that incentives will add to their costs.

It was found that the schedule $\mathrm{I} / \mathrm{D}$ type is the most widely used I/D contracting type. The other I/D types such as performance incentives and safety incentives are used, but to a smaller extent. In addition, it is concluded that mechanical completion and start-up and commissioning are two important criteria that are used to define project completion in I/D contracts. The study indicated that a rapid return on investment is one important reason why owners put $\mathrm{I} / \mathrm{D}$ provisions in some projects. Therefore, owners need to put I/D provisions on projects that will have a rapid return on investment. Adding more manpower, proper planning and scheduling of project activities, using advance equipment and construction techniques, and increasing labor productivity are the essential extra measures that a contractor has to take into consideration in $\mathrm{I} / \mathrm{D}$ contracts. The majority of the companies who participated in the study do not have a system to calculate the I/D amount; the majority of the respondents believe that the I/D amount should depend on the criticality of the project and the cost saving that will be gained. On the other hand, about one-fifth of the respondents indicated that the optimal I/D amount is $10 \%$ of the project cost and can be generalized for all projects. The participants of the study also indicated the major problems encountered in I/D projects. Study recommendations are summarized in the following points:

1. I/D contracts are usually dealt with in a rush, and the likelihood of errors by contractor are large. If the contractor wants to win the incentive, he needs to be proactive, anticipate problem areas, and fix them before occurrence.

2. Contractors need to identify and be aware of factors that influence labor productivity and implement strategies to mitigate their effects. This is not an easy task and requires an experienced contractor who knows how to deal with labor problems.

3. The general contractor needs to properly plan subcontractors' work to avoid construction problems and delays.

4. The contractors should make sure that quality is not affected due to the fast track of the project and all measures should be taken to maintain the level of quality not affected by the construction speed.

5. The contractor should be mindful of safety and should never forget that safety is always the top priority at any job site.

\section{Acknowledgements}

The author wishes to acknowledge the support given by the King Fahd University of Petroleum and Minerals during the course of this study.

\section{Appendix A. Study questionnaire}

Name (optional):

Title: Company:

1. How should the incentive amount be paid to the contractor?

\begin{tabular}{lccc}
\hline Descriptions & $\mathrm{O} \%$ & $\mathrm{C} \%$ & $\mathrm{~T} \%$ \\
\hline $\begin{array}{l}\text { A. In full upon completion of } \\
\text { some milestone activities }\end{array}$ & 0 & 0 & 0 \\
$\begin{array}{l}\text { B. Partially upon completion } \\
\text { of some milestone activities }\end{array}$ & 27 & 30 & 29 \\
$\begin{array}{l}\text { C. In full upon completion } \\
\text { of the project }\end{array}$ & 45 & 50 & 48 \\
\hline
\end{tabular}

$\mathrm{O} \%, \%$ of owners' response; $\mathrm{C} \%, \%$ of contractors' response; $\mathrm{T} \%, \%$ of total responses.

2. What is the most widely used criterion to define projects completion?

\begin{tabular}{lrrr}
\hline Descriptions & $\mathrm{O} \%$ & $\mathrm{C} \%$ & $\mathrm{~T} \%$ \\
\hline A. Mechanical completion & 27.27 & 70 & 47.6 \\
B. Project turnover to operation & 27.27 & 0 & 14.3 \\
C. Start up and commissioning & 27.27 & 30 & 28.6 \\
D. Other (please specify) & 9.09 & 0 & 4.8 \\
\hline
\end{tabular}


3. What are the reasons that encourage the use of $I / D$ contracting? Please mark all that apply.

\begin{tabular}{lccr}
\hline Descriptions & $\mathrm{O} \%$ & $\mathrm{C} \%$ & $\mathrm{~T} \%$ \\
\hline $\begin{array}{l}\text { A. Early completion will insure } \\
\text { rapid return on investment }\end{array}$ & 81.81 & 20 & 52.4 \\
$\begin{array}{l}\text { B. Project has direct influence } \\
\text { on profitable other projects }\end{array}$ & 18.18 & 10 & 14.3 \\
$\begin{array}{l}\text { C. Project is needed on a specific } \\
\text { date for safety reasons }\end{array}$ & 18.18 & 0 & 9.5 \\
$\begin{array}{l}\text { D. Project is needed as soon as } \\
\text { possible to comply to }\end{array}$ & 9.09 & 10 & 9.5 \\
government regulations & & & \\
$\begin{array}{l}\text { E. Do not know } \\
\text { F. Other (please specify) }\end{array}$ & 0 & 60 & 28.6 \\
\hline
\end{tabular}

4. At what stage should I/D provisions be included in the contract?

\begin{tabular}{lccc}
\hline Descriptions & $\mathrm{O} \%$ & $\mathrm{C} \%$ & $\mathrm{~T} \%$ \\
\hline A. At the planning stage & 9.09 & 0 & 4.8 \\
B. At the design stage & 0 & 0 & 0 \\
C. At the bidding stage & 63.63 & 10 & 38.1 \\
(negotiation with successful bidder) & & & \\
D. At the construction stage & 18.18 & 60 & 38.1 \\
E. Do not know & 0 & 30 & 14.3 \\
F. Other (please specify) & 9.09 & 0 & 4.8 \\
\hline
\end{tabular}

5. What are the extra measures that you have to take in incentive contracting?

\begin{tabular}{lccc}
\hline Descriptions & $\mathrm{O} \%$ & $\mathrm{C} \%$ & $\mathrm{~T} \%$ \\
\hline $\begin{array}{l}\text { A. Add more manpower } \\
\begin{array}{l}\text { B. Increase the number of } \\
\text { working hours }\end{array}\end{array}$ & 27.27 & 60 & 42. \\
$\begin{array}{l}\text { C. Use advanced equipment } \\
\begin{array}{l}\text { and machines, and } \\
\text { construction techniques }\end{array}\end{array}$ & 45.45 & 0 & 23.8 \\
$\begin{array}{l}\text { D. Increase workers productivity } \\
\text { by providing motivation }\end{array}$ & 45.45 & 0 & 23.8 \\
$\begin{array}{l}\text { E. Proper planning and scheduling } \\
\text { of the project activities }\end{array}$ & 45.45 & 30 & 38.1 \\
\begin{tabular}{l} 
F. Other (please specify) \\
\hline
\end{tabular} & 9.09 & 0 & 4.8 \\
\hline
\end{tabular}

6. How should the line of communication between the owner and contractor be developed?

\begin{tabular}{lcrc}
\hline Descriptions & $\mathrm{O} \%$ & $\mathrm{C} \%$ & $\mathrm{~T} \%$ \\
\hline A. By pre-design field reviews & 27.27 & 0 & 14.3 \\
B. By pre-construction meetings & 36.36 & 0 & 19.0 \\
C. By regular construction meetings & 54.54 & 100 & 76.2 \\
D. Other (please specify) & 0 & 0 & 0 \\
\hline
\end{tabular}

7. What kind of managerial techniques should the contractor use in I/D projects?

\begin{tabular}{|c|c|c|c|}
\hline Descriptions & $\mathrm{O} \%$ & $\mathrm{C} \%$ & $\mathrm{~T} \%$ \\
\hline A. Bar charts & 54.5 & 90 & 71.4 \\
\hline B. CPM & 27.3 & 10 & 19.0 \\
\hline $\begin{array}{l}\text { C. CPM with time cost trade } \\
\text { off analysis }\end{array}$ & 27.3 & 0 & 14.3 \\
\hline $\begin{array}{l}\text { D. Computerized materials } \\
\text { inventory }\end{array}$ & 9.1 & 0 & 4.8 \\
\hline $\begin{array}{l}\text { E. Computerized equipment } \\
\text { management }\end{array}$ & 9.1 & 0 & 4.8 \\
\hline $\begin{array}{l}\text { F. Computerized communication } \\
\text { system (E mail) }\end{array}$ & 0 & 0 & 0 \\
\hline
\end{tabular}

8. Which of the following schemes does the contractor have to use to expedite the work schedule? Please mark all that apply.

\begin{tabular}{lcrr}
\hline Descriptions & $\mathrm{O} \%$ & $\mathrm{C} \%$ & $\mathrm{~T} \%$ \\
\hline A. Six day work week & 72.7 & 0 & 38.1 \\
B. Seven day work week & 0 & 80 & 38.1 \\
C. Two shifts & 36.4 & 0 & 19.0 \\
D. Three shifts & 9.1 & 0 & 4.8 \\
E. Multiple work crews in & 54.5 & 20 & 38.1 \\
multiple areas & & & \\
\hline
\end{tabular}

9. What special personnel and manpower policy should be adopted by the contractor to fulfill the I/D targets?

\begin{tabular}{lccc}
\hline Descriptions & $\mathrm{O} \%$ & $\mathrm{C} \%$ & $\mathrm{~T} \%$ \\
\hline $\begin{array}{l}\text { A. Special consideration in } \\
\text { selecting subcontractors }\end{array}$ & 45.5 & 50 & 47.6 \\
$\begin{array}{l}\text { B. Special consideration in } \\
\text { appointing senior project personnel }\end{array}$ & 36.4 & 10 & 23.8 \\
$\begin{array}{l}\text { C. Special consideration in } \\
\text { selecting field personnel }\end{array}$ & 36.4 & 70 & 52.4 \\
$\begin{array}{l}\text { D. Using outside consultants } \\
\text { E. Don't know }\end{array}$ & 0 & 0 & 0 \\
\hline
\end{tabular}


10. Should the contractor pass the incentive down to the personnel? If yes, down to what level?

\begin{tabular}{lccc}
\hline Descriptions & $\mathrm{O} \%$ & $\mathrm{C} \%$ & $\mathrm{~T} \%$ \\
\hline A. Yes, down to upper management & 0 & 10 & 4.8 \\
B. Yes, down to middle management & 27.3 & 20 & 23.8 \\
C. Yes, down to workers & 9.1 & 50 & 28.6 \\
D. No & 0 & 0 & 0 \\
E. Don't know & 27.3 & 10 & 19.0 \\
\hline
\end{tabular}

11. What are the difficulties that the contractor may experience due to labor agreements?

\section{Descriptions}
A. Optimizing crew sizes
B. Adjusting scheduled over time
$\begin{array}{lll}0 & 20 & 9.5\end{array}$
C. Setting wages in second or third shifts $\begin{array}{llll}0 & 0 & 0\end{array}$
D. Increasing labor productivity $\quad 45.560 \quad 52.4$
E. Other (please specify)
$\begin{array}{lll}0 & 10 & 4.8\end{array}$

$\mathrm{O} \% \mathrm{C} \% \mathrm{~T} \%$

12. What is the frequency of change orders in $\mathrm{I} / \mathrm{D}$ projects compared with an average non $\mathrm{I} / \mathrm{D}$ project?

\begin{tabular}{lccc}
\hline Descriptions & $\mathrm{O} \%$ & $\mathrm{C} \%$ & $\mathrm{~T} \%$ \\
\hline $\begin{array}{l}\text { A. As frequent as in an } \\
\text { average non-I/D project }\end{array}$ & 9.1 & 0 & 4.8 \\
$\begin{array}{l}\text { B. More frequent than in an } \\
\text { average non-I/D project }\end{array}$ & 0 & 0 & 0 \\
$\begin{array}{l}\text { C. Less frequent than in an } \\
\text { average non-I/D project }\end{array}$ & 27.3 & 20 & 23.8 \\
\begin{tabular}{l} 
D. Do not know \\
\hline
\end{tabular} & 36.4 & 80 & 57.1 \\
\hline
\end{tabular}

13. What is the magnitude of change orders in $I / D$ projects compared to an average non-I/D project?

\begin{tabular}{lccc}
\hline Descriptions & $\mathrm{O} \%$ & $\mathrm{C} \%$ & $\mathrm{~T} \%$ \\
\hline $\begin{array}{l}\text { A. As big as in an average } \\
\text { non-I/D project }\end{array}$ & 18.2 & 0 & 9.5 \\
$\begin{array}{l}\text { B. Bigger than in an average } \\
\text { non-I/D project }\end{array}$ & 0 & 0 & 0 \\
$\begin{array}{l}\text { C. Less than in an average } \\
\text { non-I/D project }\end{array}$ & 27.3 & 10 & 19.0 \\
\begin{tabular}{l} 
D. Don't know \\
\hline
\end{tabular} & 9.1 & 70 & 38.1 \\
\hline
\end{tabular}

14. Would projects last longer if they are non-I/D projects?

\begin{tabular}{lrrr}
\hline Descriptions & $\mathrm{O} \%$ & $\mathrm{C} \%$ & \multicolumn{1}{c}{$\mathrm{T} \%$} \\
\hline A. Yes, by _\% & 45.5 & 60 & 52.4 \\
B. No & 18.2 & 0 & 9.5 \\
C. Don't know & 9.1 & 20 & 14.3 \\
\hline
\end{tabular}

15. What are the benefits of incentives/disincentive contracting?

\begin{tabular}{lccc}
\hline Descriptions & $\mathrm{O} \%$ & $\mathrm{C} \%$ & $\mathrm{~T} \%$ \\
\hline $\begin{array}{l}\text { A. Encourage contractors to } \\
\text { expedite the construction work }\end{array}$ & 90.9 & 70 & 38.1 \\
$\begin{array}{l}\text { B. Encourage contractors to } \\
\text { find ways to reduce cost }\end{array}$ & 18.2 & 10 & 14.3 \\
$\begin{array}{l}\text { C. Allocate some of the risk to } \\
\text { the contractor }\end{array}$ & 9.1 & 10 & 9.5 \\
$\begin{array}{l}\text { D. Encourage contractors to } \\
\text { furnish quality and safe work }\end{array}$ & 18.2 & 20 & 19.0 \\
\begin{tabular}{l} 
E. Other (please specify) \\
\hline
\end{tabular} & 9.1 & 0 & 4.8 \\
\hline
\end{tabular}

16. How do you decide (calculate) the amount of incentive?

\begin{tabular}{llll}
\hline Descriptions & $\mathrm{O} \%$ & $\mathrm{C} \%$ & $\mathrm{~T} \%$ \\
\hline $\begin{array}{l}\text { A. It depends on the risk } \\
\text { allocation on each party }\end{array}$ & 36.4 & 50 & 42.9 \\
$\begin{array}{l}\text { B. Using empirical formula } \\
\text { (please write down the formula) }\end{array}$ & 36.4 & 10 & 23.8 \\
$\begin{array}{l}\text { C. Use always 10\% (constant } \\
\text { for all projects) of the project cost }\end{array}$ & 27.3 & 0 & 14.3 \\
$\begin{array}{l}\text { D. Depending on the amount } \\
\text { that will be lost as a result of }\end{array}$ & 0 & 20 & 9.5 \\
\begin{tabular}{l} 
late completion \\
\hline
\end{tabular} & & & \\
\hline
\end{tabular}

17. How do you decide (calculate) the amount of penalty?

\begin{tabular}{|c|c|c|c|}
\hline Descriptions & $\mathrm{O} \%$ & $\mathrm{C} \%$ & $\mathrm{~T} \%$ \\
\hline $\begin{array}{l}\text { A. It depends on the risk } \\
\text { allocation on each party }\end{array}$ & 0 & 20 & 9.5 \\
\hline $\begin{array}{l}\text { B. Using empirical formula } \\
\text { (please write down the formula) }\end{array}$ & 0 & 0 & 0 \\
\hline $\begin{array}{l}\text { C. Depending on the cost saving } \\
\text { that will be gained as a result } \\
\text { of early completion }\end{array}$ & 36.4 & 30 & 33.3 \\
\hline $\begin{array}{l}\text { D. Use always } 10 \% \text { (constant for } \\
\text { all projects) of the project cost }\end{array}$ & 36.4 & 60 & 47.6 \\
\hline E. Other (please specify) & 9.1 & 0 & 4.8 \\
\hline
\end{tabular}


18. What is the optimal amount of incentive per project? Descriptions

\begin{tabular}{lccc} 
A. $5 \%$ of the project cost & 18.2 & 0 & 9.5 \\
B. $10 \%$ of the project cost & 27.3 & 10 & 19.0 \\
C. $15 \%$ of the project cost & 0 & 0 & 0 \\
D. $20 \%$ of the project cost & 0 & 0 & 0 \\
$\begin{array}{l}\text { E. It depends on the criticality } \\
\text { of the project and the cost }\end{array}$ & 63.6 & 80 & 71.4 \\
saving that will be gained & & & \\
F. Other (please specify) & 9.1 & 10 & 9.5 \\
\hline
\end{tabular}

\section{Penalties:}

\begin{tabular}{|c|c|c|c|}
\hline Descriptions & $\mathrm{O} \%$ & $\mathrm{C} \%$ & $\mathrm{~T} \%$ \\
\hline A. Force contractors to be proactive & 36.4 & 50 & 42.9 \\
\hline B. Improve contractors productivity & 36.4 & 10 & 23.8 \\
\hline $\begin{array}{l}\text { C. Force contractors to complete } \\
\text { projects as planned and within } \\
\text { budget but it will scarify the } \\
\text { quality of the work }\end{array}$ & 36.4 & 20 & 28.6 \\
\hline $\begin{array}{l}\text { D. The amount of penalty should } \\
\text { not exceed } 10 \% \text { of the project cost }\end{array}$ & 27.3 & 0 & 14.3 \\
\hline E. Other (please specify) & 0 & 20 & 0 \\
\hline
\end{tabular}

\section{The amount of incentive and penalty should be:}

\begin{tabular}{lccc}
\hline Descriptions & $\mathrm{O} \%$ & $\mathrm{C} \%$ & $\mathrm{~T} \%$ \\
\hline $\begin{array}{l}\text { A. Assigned equally } \\
\text { (i.e. 10\% incentive, }\end{array}$ & 54.5 & 0 & 28.6 \\
$\begin{array}{l}\text { and } 10 \% \text { penalty). } \\
\begin{array}{l}\text { B. Incentive should be more } \\
\text { than penalty }\end{array}\end{array}$ & 9.1 & 80 & 42.9 \\
$\begin{array}{l}\text { C. Penalty should be more } \\
\text { than incentive }\end{array}$ & 27.3 & 0 & 14.3 \\
\begin{tabular}{l} 
D. Other (please specify) \\
\hline
\end{tabular} & 9.1 & 10 & 9.5 \\
\hline
\end{tabular}

\section{References}

[1] Gilbreath RD. Managing construction contracts. New York: John Wiley, 1983.

[2] Stukhart G. Contractual incentives. Journal of Construction Engineering and Management 1984;110(1):34-42.

[3] Arditi D, Yasamis F. Incentive/disincentive contracts perceptions of owners and contractors. Journal of Construction Engineering and Management 1998;124(5):361-71.

[4] Clough RH. Construction contracting. New York: John Wiley, 1981.

[5] Hinze JW. Construction safety. Columbus, Ohio: Prentice Hall, 1997. 